\title{
Pawpaw [Asimina triloba (L.) Dunal] Fruit Ripening. I. Ethylene Biosynthesis and Production
}

\author{
Rumphan Koslanund ${ }^{1}$ \\ Post-Harvest Products and Processing Research and Development Office, Department of Agriculture, \\ Bangkok, Thailand \\ Douglas D. Archbold² \\ Department of Horticulture, University of Kentucky, Lexington, KY 40546-0091 \\ Kirk W. Pomper ${ }^{3}$ \\ USDA National Clonal Germplasm Repository for Asimina spp., Atwood Research Facility, Kentucky \\ State University, Frankfort, KY 40601-2355
}

\begin{abstract}
AdDitional IndeX words. 1-aminocyclopropane-1-carboxylic acid, ACC, ACC synthase, ACC oxidase, malonyl-ACC
Abstract. Pawpaw fruit ethylene production, 1-aminocyclopropane-1-carboxylic acid (ACC) synthase (ACS) and ACC oxidase (ACO) activities, and tissue content of the ethylene precursor ACC and conjugate malonyl-ACC (MACC) were measured during postharvest ripening. Fruit were harvested near the advent of the ripening process and were ripened at room temperature. The fruit displayed increases in ethylene production and respiration rate during ripening with maxima for both 3 days after harvest. Mean ethylene maxima on a fresh weight basis were 4.7 and $7.6 \mu \mathrm{g} \cdot \mathrm{kg}^{-1} \cdot \mathrm{h}^{-1} \mathrm{and}$ mean respiratory $\left(\mathrm{CO}_{2}\right.$ production) maxima on a fresh weight basis were 220 and $239 \mathrm{mg} \cdot \mathrm{kg}^{-1} \cdot \mathrm{h}^{-1}$ in 1999 and 2001 , respectively. The increase in ethylene evolution coincided with an increase in respiration and a rapid decline in fruit firmness. Internal and external fruit firmness declined in a parallel manner. The ethylene climacteric peak occurred after the greatest decline in fruit firmness, indicating that low levels of ethylene may be sufficient to initiate the ripening process. The ethylene climacteric peak also coincided with the highest activities of both ACS and ACO as well as the maximum tissue ACC content. As ACC content increased, MACC content declined, suggesting a regulation of ethylene production via free ACC levels by malonylation of ACC. Thus, the climacteric development of ethylene production may be regulated by an increase of ACS activity and a decrease in ACC malonyltransferase activity, making more free ACC available for the production of ethylene by increased activity of ACO.
\end{abstract}

The pawpaw belongs to the Annonaceae family, which includes cherimoya (Annona cherimola Mill.), sweetsop or sugar apple (Annona squamosa L.), custard apple (Annona reticulata L.), atemoya (Annona squamosa $\times$ A. cherimola), and soursop (Annona muricata L.). The genus Asimina Dunal is the only temperate zone member of this tropical family (Darrow, 1975; Kral, 1960). The few earlier studies of pawpaw ripening have described qualitative changes including an increase in soluble solids content, a rise in volatile production, and rapid loss of firmness (McGrath and Karahadian, 1994a, 1994b; Shiota, 1991). The shelf life of pawpaw fruit at ambient temperature does not exceed $5 \mathrm{~d}$, although cold storage may delay ripening for at least $30 \mathrm{~d}$ (Archbold and Pomper, 2003). The rapid rate of pawpaw ripening and deterioration may have led to its lack of horticultural attention to date.

Although pawpaw was initially confused in literature reviews with papaya and mistakenly characterized as a climacteric fruit many years ago, it does in fact exhibit respiratory and ethylene climacterics $\approx 3 \mathrm{~d}$ after harvest when held at ambient temperature (Archbold et al., 2003; Archbold and Pomper, 2003). The other Annonaceae fruit noted above are climacteric as well (Brown et al., 1988; Martinez et al., 1993; Paull, 1982; Tsay and Wu, 1989;

Received for publication 25 May 2004. Accepted for publication 14 Jan. 2005. 'Former: Graduate Student, Dept. of Horticulture, Univ. of Kentucky, Lexington, KY 40546-0091.

${ }^{2}$ Professor of Horticulture. To whom reprint requests should be addressed.

${ }^{3}$ Principal Investigator of Horticulture and Curator.
Wills et al., 1984). For climacteric fruit, ethylene is generally thought to regulate fruit ripening by coordinating the expression of genes responsible for 1) enhancing a rise in the rate of respiration, 2) autocatalytic ethylene production, 3) chlorophyll degradation, 4) pigment synthesis, 5) conversion of starch to sugars, 6) production of aroma volatiles, and 7) increased activity of cell-wall degrading enzymes (Gray et al., 1992). In the ethylene-biosynthetic pathway, S-adenosylmethionine (SAM) is converted to ACC by ACS, while ACO catalyzes the conversion of ACC to ethylene (Yang and Hoffman, 1984). The levels of free ACC may be regulated via malonylation of ACC to MACC, which could affect ethylene production (Lelievre et al., 1997). In mature climacteric fruit, ethylene is autostimulatory and inhibitors of ethylene action block ethylene production and ripening (Lelievre et al., 1997; Oetiker and Yang, 1995). Positive feedback regulation of ethylene biosynthesis is a characteristic feature of ripening climacteric fruit and senescing flowers (Nakatsuka et al., 1998).

Due to a need to slow the rapid rate of ripening and consequent deterioration of pawpaw fruit and the potential role of ethylene in mediating the process, the objective of this research was to study the pattern of ethylene production and respiration during pawpaw fruit ripening after harvest in relation to the activities of ACS and ACO and the levels of ACC and MACC.

\section{Materials and Methods}

Plant material. Pawpaw fruit were harvested at the first sign of softening as determined by touch from 22 and 28 genotypes at the Kentucky State Univ. Research Farm, Frankfort, on several 
dates in 1999 and 2001. Immediately following harvest, fruit were transported to the laboratory at the Univ. of Kentucky. Because preliminary work in 1998 indicated no appreciable variation in ripening pattern among genotypes and the intent was to characterize general trends of pawpaw fruit ripening, not possible clonal differences, the fruit from the different genotypes were pooled for use, and data was pooled across harvest dates within each year.

MEASUREMENT OF ETHYLENE PRODUCTION AND RESPIRATION. Ethylene production and respiration rate were determined at ambient temperature $\left(22 \pm 2{ }^{\circ} \mathrm{C}\right)$ during ripening after harvest in 1999 at $0,1,2,3,5$, and $7 \mathrm{~d}$ with replication of $72,53,43$, 43,30 , and 30 fruit, respectively, and in 2001 at $0,1,2,3,4,5$, and $6 \mathrm{~d}$ with replication of 59, 55, 40, 34, 22, 17, and 8 fruit, respectively. Replicate numbers declined as fruit were sampled for destructive analyses in this and other studies.

Individual fruit were weighed and placed in a 0.98 -L bottle at room temperature that was capped for $2 \mathrm{~h}$. For $\mathrm{C}_{2} \mathrm{H}_{4}$ quantification, 1-mL gas samples were withdrawn from the bottle headspace by inserting a syringe through a fitted septum, and injected into a Varian 2100 gas chromatograph (Varian, Palo Alto, Calif.) fitted with a $1-\mathrm{m}$ alumina column, run at $100 / 70 / 100{ }^{\circ} \mathrm{C}$ for the injector/ column/flame ionization detector temperatures, respectively. The $\mathrm{N}_{2}$ carrier gas flow rate was $30 \mathrm{~mL} \cdot \mathrm{min}^{-1}$. Ten-milliliter gas samples were withdrawn from the bottles to determine $\mathrm{CO}_{2}$ production using an Oxygen/Carbon Dioxide Headspace Analyzer ZR 892 HS (Illinois Instruments, McHenry, Ill.). Fruit volume was subtracted from bottle volume using a fruit weight vs. volume regression (volume $=1.79+0.81 \times$ fresh weight; $r=0.8, P<0.01$ ) to calculate $\mathrm{C}_{2} \mathrm{H}_{4}$ and $\mathrm{CO}_{2}$ production per unit fruit weight per hour.

Fresh WEIGHT AND FIRMNESS MEASUREMENT. Fruit external firmness was determined using a Chatillon Digital Force Gauge (model DFM 10; John Chatillon and Sons, Greensboro, N.C.) mounted on a model LTC test stand and equipped with a 2-mm flat probe. Fruit were measured at harvest and after 3 and $7 \mathrm{~d}$ in 1999 on 88,59 , and 36 fruit, respectively, and at harvest and $1,2,3,4,5$, and $6 \mathrm{~d}$ in 2001, with replication of 59, 55, 40, 34, 22,17 , and 8 fruit, respectively. The firmness of each fruit was measured as deformation resistance on two opposite sides of the equatorial region by the force required for a 2-mm compression and is expressed in Newtons (N). Fruit internal firmness was measured at harvest and after 3 and $7 \mathrm{~d}$ in 1999 on 28, 21, and 36 fruit, respectively, and at harvest and 1, 2, 3, 4, 5, and $6 \mathrm{~d}$ in 2001 , with $8,15,8,10,9$, and 8 fruit, respectively. Following removal of the peel to expose the flesh, the internal firmness was determined as penetration resistance by the force required for a 5-mm penetration of a cone probe, mounted in place of the flat probe, on two opposite sides of the equatorial region and is expressed in Newtons. Following internal firmness measurements, fruit were then frozen in liquid $\mathrm{N}_{2}$ and stored at $-80{ }^{\circ} \mathrm{C}$ for subsequent analyses.

ACC AND MACC QuAnTification. ACC was quantified by the method of McKeon et al. (1982) with some modifications. One gram frozen flesh tissue was macerated in $5 \mathrm{~mL}$ ethanol by mortar and pestle and extracted twice with $10 \mathrm{~mL} 80 \%$ ethanol at $70^{\circ} \mathrm{C}$ for $30 \mathrm{~min}$. The ethanol extracts were combined and dried to a low volume under a stream of $\mathrm{N}_{2}$ and low heat, placed in -80 ${ }^{\circ} \mathrm{C}$ for $1 \mathrm{~h}$, and lyophilized. The dried residue was redissolved in $0.5 \mathrm{~mL}$ chloroform, and the ACC was extracted with $2.5 \mathrm{~mL}$ of water. The solution was centrifuged at low centrifugal force $(2500$ $g_{\mathrm{n}}$ ) for $10 \mathrm{~min}$ to separate aqueous extract from chloroform. The ACC content in the aqueous extract was determined by chemical conversion of ACC to ethylene according to the method of
Lizada and Yang (1979). The reaction mixture consisted of a 500- $\mu \mathrm{L}$ aliquot of the above ACC extract and $4 \mu \mathrm{M} \mathrm{HgCl}_{2}$, and the volume was brought up to $1800 \mu \mathrm{L}$ with water. These reaction tubes were kept on ice. After the addition of $200 \mu \mathrm{L}$ of a cold mixture of $5 \% \mathrm{NaOCl}$ and saturated $\mathrm{NaOH}(2: 1 ; \mathrm{v} / \mathrm{v})$, the test tube was immediately sealed with a serum stopper. The test tube was then vortexed for $10 \mathrm{~s}$ and returned to ice for $2 \mathrm{~min}$. Prior to gas sampling, the reaction mixture was vortexed for another $10 \mathrm{~s}$, and a $1-\mathrm{mL}$ gas sample was then withdrawn for ethylene analysis by gas chromatography (GC).

MACC was quantified by the method of Hoffman et al. (1983). A $500-\mu \mathrm{L}$ aliquot of the above ACC extract was treated by adding $1 \mathrm{~mL} 2 \mathrm{~N} \mathrm{HCl}$ and placing it in a $100{ }^{\circ} \mathrm{C}$ water bath for $3 \mathrm{~h}$ to hydrolyze MACC to ACC. The solution was cooled on ice for 15 $\mathrm{min}$, and was then neutralized with $0.5 \mathrm{~mL} 4 \mathrm{~N} \mathrm{NaOH}$. The solution was frozen, lyophilized, and re-dissolved in $0.5 \mathrm{~mL}$ water. The ACC content was determined as above. The concentration of MACC was calculated as the difference in ACC before and after hydrolysis. The ACC and MACC results are expressed as nanomoles per $100 \mathrm{~g}$ dry weight (DW).

In VITRo ACS ACTIVITY. ACS activity was measured by the methods of Yip and Yang (1993) with some modifications. Upon removal of fruit from $-80{ }^{\circ} \mathrm{C}$ storage, flesh tissue $(10 \mathrm{~g})$ was ground in liquid $\mathrm{N}_{2}$ with a mortar and pestle. The macerate was homogenized (Omni 5000; Omni Intl., Gainesville, Va.) in 30 $\mathrm{mL}$ ice-cold buffer containing $400 \mathrm{~mm}$ potassium phosphate $(\mathrm{pH}$ 8.5), $10 \mu \mathrm{M}$ pyridoxal 5-phosphate (PLP), $4 \mathrm{~mm}$ dithiothreitol (DTT), and $20 \%$ glycerol. The homogenate was filtered through four layers of cheesecloth and 1 layer of Miracloth (Calbiochem, EMD Biosciences, La Jolla, Calif.) and then centrifuged at 48,400 $g_{\text {n }}$ and $4{ }^{\circ} \mathrm{C}$ for $20 \mathrm{~min}$. The resulting supernatant $(0.5 \mathrm{~mL})$ was filtered through a G-50 Sephadex (Sigma Chemical Co., St. Louis) column (10 mL bed volume) that had been equilibrated with $20 \mathrm{~mm}$ potassium phosphate ( $\mathrm{pH} 8.5$ ), $10 \mu \mathrm{M}$ PLP, $0.1 \mathrm{~mm}$ DTT, and $20 \%$ glycerol. The protein fraction in the void volume $(2 \mathrm{~mL})$ was collected for the ACS activity assay. Aliquots of enzyme preparation were incubated at $30^{\circ} \mathrm{C}$ for $30 \mathrm{~min}$ with 50 mM K-HEPES (pH 8.0), $10 \mu \mathrm{M}$ PLP, and $200 \mu \mathrm{M}$ SAM in a total volume of $0.6 \mathrm{~mL}$. The reaction was initiated by adding SAM and stopped by adding $300 \mu \mathrm{L}$ of $13.33 \mathrm{mM} \mathrm{HgCl}_{2}$. Then, 100 $\mu \mathrm{L}$ of $2: 1 \mathrm{NaOCl}: \mathrm{NaOH}$ was added to the samples. ACS activity was assayed by following the formation of ACC. The amount of ACC formed was determined according to Lizada and Yang (1979) as above.

In VITRO ACO ACTIVITY. ACO activity was measured by the method of Yip and Yang (1993) with some modification. Upon removal from $-80{ }^{\circ} \mathrm{C}$ storage, flesh tissue $(10 \mathrm{~g})$ was ground in liquid $\mathrm{N}_{2}$ with a mortar and pestle. The macerate was homogenized in $75 \mathrm{~mL}$ of extraction medium containing $0.1 \mathrm{M}$ Tricine $(\mathrm{pH}$ 7.5), $10 \%$ glycerol, $30 \mathrm{~mm}$ ascorbate, $1 \mathrm{~mm}$ DTT, and 5\% (w/w) polyvinylpolypyrrolidone (PVPP) (Dong et al., 1992). After the slurry thawed, it was filtered through four layers of cheesecloth and centrifuged at $48,400 g_{\mathrm{n}}$ and $4{ }^{\circ} \mathrm{C}$ for $20 \mathrm{~min}$. The supernatant was used for enzyme assays. The enzyme assay reaction was initiated by combining $600 \mu \mathrm{L}$ extracted enzyme, $400 \mu \mathrm{L}$ assay solution containing $0.1 \mathrm{M}$ Tricine ( $\mathrm{pH} 7.5), 10 \%$ glycerol, $0.1 \mathrm{~mm}$ $\mathrm{FeSO}_{4}, 30$ mм ascorbate, 1 mм DTT (Poneleit and Dilley, 1993), and 0.25 mm sodium bicarbonate (Smith and John, 1993), and 1.9 mM ACC. The test tube was then sealed and after incubation with shaking at $25^{\circ} \mathrm{C}$ for $20 \mathrm{~min}$, a 1-mL gas sample was withdrawn with a syringe from the headspace for $\mathrm{C}_{2} \mathrm{H}_{4}$ determination using the GC described previously. 
Data analysis. To determine if daily means varied significantly, data were analyzed using SAS (SAS Institute, Cary, N.C.), and means were separated by least significant difference at $P=0.05$.

\section{Results and Discussion}

ETHYLENE PRODUCTION AND RESPIRATION. Ripening pawpaw fruit exhibited an ethylene climacteric peak $3 \mathrm{~d}$ after harvest both years (Fig. 1). The related sugar apple (Tsay and Wu, 1989), cherimoya (Sanchez et al., 1998), and soursop (Paull, 1982) exhibited ethylene peaks 3, 5, and $6 \mathrm{~d}$ after harvest, respectively. In 1999 the mean peak ethylene production was $7.6 \mu \mathrm{g} \cdot \mathrm{kg}^{-1} \cdot \mathrm{h}^{-1}$ on a fresh weight basis, and in 2001 the mean peak ethylene production was $4.6 \mu \mathrm{g} \cdot \mathrm{kg}^{-1} \cdot \mathrm{h}^{-1}$. In an earlier study, pawpaw fruit that were softer at harvest exhibited an ethylene climacteric at $3 \mathrm{~d}$ while the most firm fruit didn't reach a climacteric until $5 \mathrm{~d}$ after harvest (Archbold and Pomper, 2003). Among the Annonaceae, the ethylene production rates of pawpaw are low compared to cherimoya, atemoya, and soursop, which range from $50-300 \mu \mathrm{g} \cdot \mathrm{kg}^{-1} \cdot \mathrm{h}^{-1}$, but similar to that of sugar apple (Alique and Zamorano, 2000; Bruinsma and Paull, 1984; Kosiyachinda and Young, 1975; Merodio and De la Plaza, 1997; Sanchez et al., 1998; Tsay and Wu, 1989). Compared to a broader range of species considered climacteric, the magnitude of the increase in ethylene production from har-

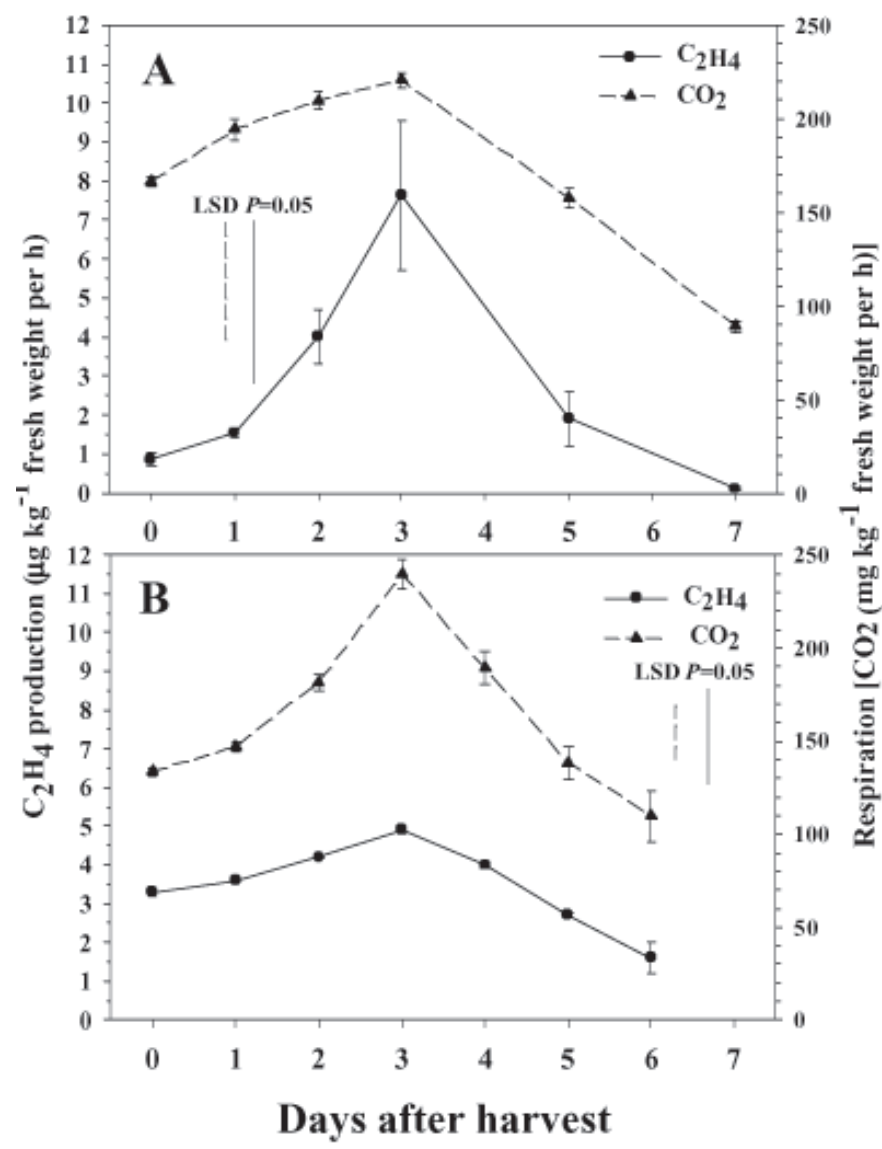

Fig. 1. Ethylene $\left(\mathrm{C}_{2} \mathrm{H}_{4}\right)$ production and respiration rate $\left(\mathrm{CO}_{2}\right.$ production $)$ on a fresh weight basis of pawpaw fruit in 1999 (A) and 2001 (B). The 1999 means for days $0,1,2,3,5$, and 7 are from $72,53,43,43,31$, and 30 fruit, respectively. The 2001 means for days $0,1,2,3,4,5$, and 6 are from $59,55,40,34,22,17$, and 8 fruit, respectively. Vertical bars on symbols represent \pm SE of the mean. The larger separate vertical bars are Fisher's least significant difference (LSD) at $P=0.05$. vest day to peak values and the maximum ethylene production rates are low (Watkins, 2002). The climacteric rise in respiration rate peaked at $3 \mathrm{~d}$ after harvest both years (Fig. 1). The mean $\mathrm{CO}_{2}$ production maxima on a fresh weight basis were 220 and $239 \mathrm{mg} \cdot \mathrm{kg}^{-1} \cdot \mathrm{h}^{-1}$ in 1999 and 2001, respectively. The respiratory peak coincided with that for ethylene production, as observed in a prior study of pawpaw (Archbold and Pomper, 2003). Some Annonaceae exhibit two respiratory peaks (Biale and Barcus, 1970); the first may be a consequence of altered carbohydrate metabolism following harvest and the second specifically related to fruit ripening (Bruinsma and Paull, 1984). Although pawpaw ethylene production was low, the respiration rates of pawpaw fruit were comparable to the other Annonaceae.

Fruit FIRMNESS. Both external and internal firmness of pawpaw fruit decreased over time in a parallel manner (Fig. 2). The skin of the pawpaw is somewhat leathery, and never becomes soft, while the flesh becomes extremely soft. The values cannot be directly compared as external firmness was tested by compression and is a measure of a composite of the traits of both skin and flesh, while the internal firmness was tested by penetration. Compression values $>20 \mathrm{~N}$ indicate firm fruit. In 2001 fruit were firmer at harvest than in 1999, suggesting harvest at an earlier stage of ripening, with external measurements of $24.6 \mathrm{~N}$ vs. $9.8 \mathrm{~N}$. The most dramatic decrease in external firmness took place between the day of harvest and the subsequent measurement date both years, as ethylene production and respiration increased but before they peaked. This was noted in an earlier study of pawpaw ripening (Archbold and Pomper, 2003). In cherimoya, flesh firmness declined rapidly during the $2 \mathrm{~d}$ after harvest, coincident with the onset of the climacteric rise in respiration rate and before any significant rise in ethylene production was observed (Martinez et al., 1993; Sanchez et al., 1998). Because pawpaw fruit soften considerably before ethylene production reaches maximum values, the threshold level at which ethylene may initiate the process may be low.

ACC and MACC Quantification. In 1999, ACC levels were $0.98 \pm 0.04 \mathrm{nmol} \cdot \mathrm{g}^{-1}$ on a FW basis at harvest, increased to 2.80 $\pm 0.34 \mathrm{nmol} \cdot \mathrm{g}^{-1} 3 \mathrm{~d}$ later, and declined to $1.29 \pm 0.23 \mathrm{nmol} \cdot \mathrm{g}^{-1}$

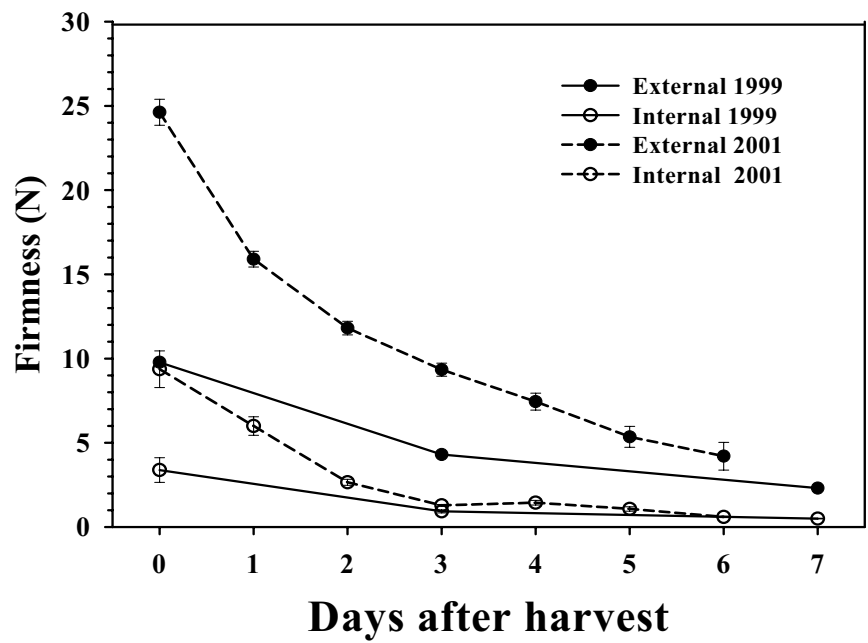

Fig. 2. Pawpaw fruit firmness after harvest in 1999 and 2001. On days 0, 3, and 7 in 1999, means for external firmness are from 88, 59, and 36 fruit, and means for internal firmness are from 28, 21, and 36 fruit, respectively. On days 0,1 , $2,3,4,5$, and 6 in 2001, means for external firmness are from 59, 55, 40, 34, 22,17 , and 8 fruit, and means for internal firmness are from $8,15,8,10,9$, and 8 fruit, respectively. Vertical bars on symbols are \pm SE of the means and are smaller than the symbol if not visible. 


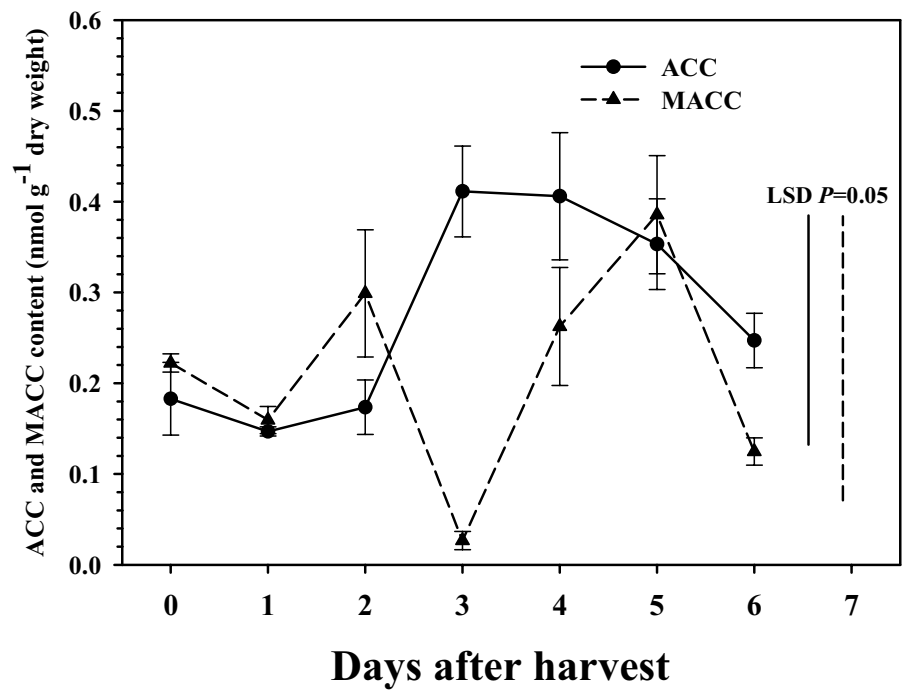

Fig. 3.Aminocyclopropane-1-carboxylic acid (ACC) and malonyl-ACC (MACC) content of pawpaw fruit tissue on a dry weight basis after harvest. Means are from four fruit on each sampling day. Vertical bars on symbols represent \pm SE of the mean. The larger separate vertical bars are Fisher's least significant difference (LSD) at $P=0.05$.

at $7 \mathrm{~d}$ after harvest (data not shown). In 2001, ACC levels were low $\left(0.18 \mathrm{nmol} \cdot \mathrm{g}^{-1}\right)$ on the harvest day and increased dramatically after day 2 (Fig. 3). ACC reached maximum values on day 3 , coinciding with the peak of ethylene production (Fig. 1). In 2001, MACC levels were slightly higher than those of ACC on the harvest day, and they were a minimum on day 3 (Fig. 3). MACC levels then dramatically increased on day 4, reached a maximum value on day 5 , and markedly dropped on day 6 . In cherimoya MACC content was high during the preclimacteric period ( $1 \mathrm{~d}$ after harvest) at $85 \%$ of total ACC, increased slightly at the beginning of the ethylene climacteric, and was $40 \%$ of total ACC at the third and fourth day after harvest (Martinez et al., 1993). In the postclimacteric period the amount of MACC increased to $55 \%$ of total ACC.

The variation in MACC levels may indicate that malonylation regulates ACC availability in pawpaw as noted in other species (Lelievre et al., 1997; Martinez et al., 1993). Although malonylation of ACC may function as a regulator of ethylene production, little is known about ACC N-malonyltransferase and how it is regulated (Martin and Saftner, 1995). Another ACC derivative, $\gamma$-glutamyl ACC or GACC, is also present in many species, and its potential role in regulating ACC levels is yet to be determined (Lelievre et al., 1997; Martin et al., 1995).

IN VITRO ACS AND ACO ACTIVITIES. The activities of both ACS and ACO were very low at harvest (Figs. 4 and 5). Both then increased, reaching maximum activities at $3 \mathrm{~d}$ after harvest both years. This coincided with the peak of ethylene production (Fig. 1). The highest activity of ACS enzyme, which produces ACC, and the maximum tissue ACC content (Fig. 3) also occurred at 3 $\mathrm{d}$ after harvest. From 4 to $6 \mathrm{~d}$ after harvest, both ACS and ACO activities decreased. Martinez et al. (1993) found a similar pattern in the related cherimoya, and the same has been observed in other climacteric fruit (Yang and Hoffman, 1984). The magnitude of the changes in ACS and ACO activities was less in 1999 than in 2001. This, combined with the greater ethylene production rates in 1999 than in 2001, suggest that the enzyme activities alone may not dictate ethylene production rates.

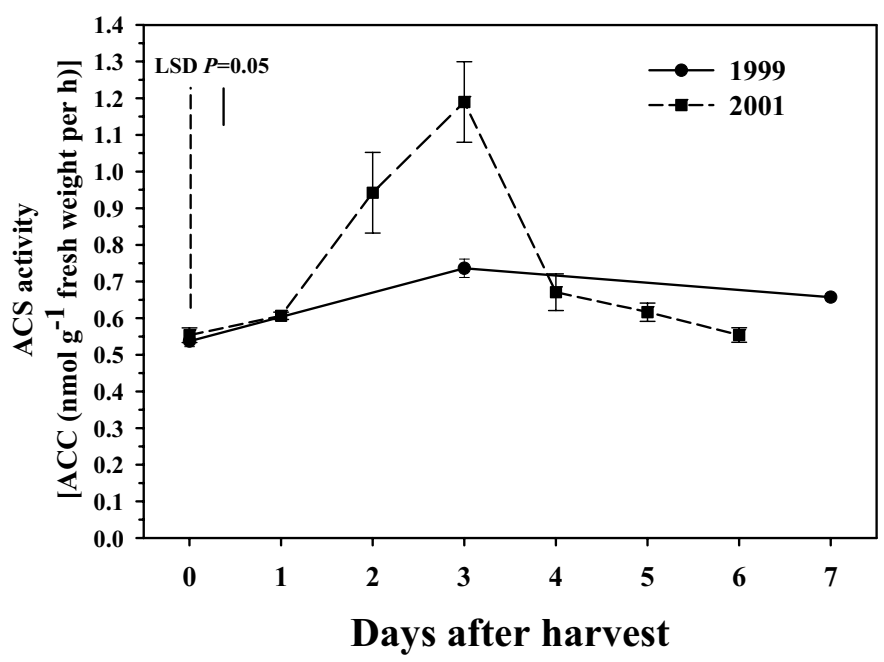

Fig. 4. Aminocyclopropane-1-carboxylic acid synthase (ACS) activity in pawpaw fruit tissue on a fresh weight basis after harvest in 1999 and 2001. Means are from four fruit in 2001 on each sampling day. Vertical bars on symbols represent \pm SE of the mean. The larger separate vertical bars are Fisher's least significant difference (LSD) at $P=0.05$.

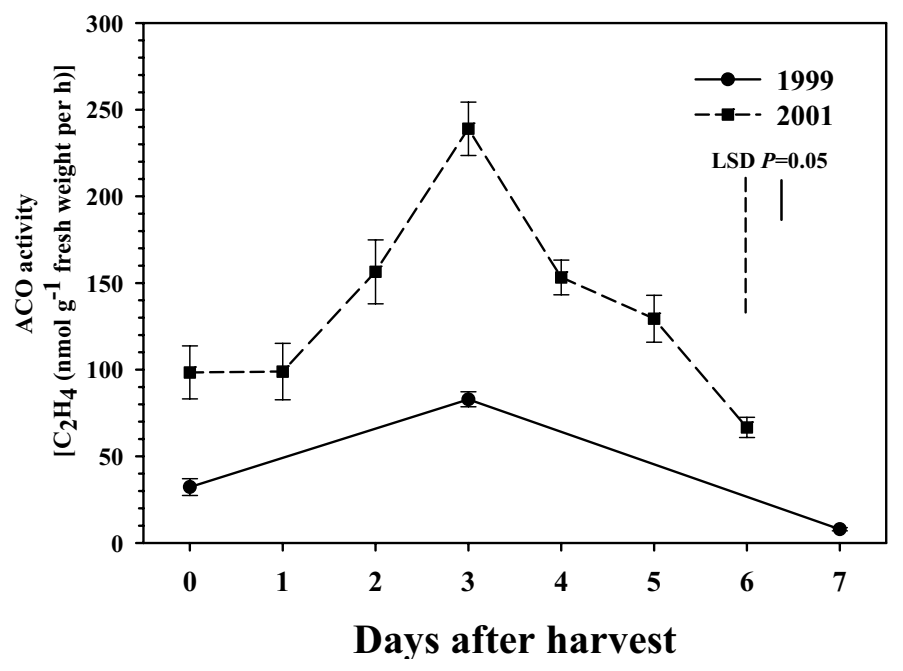

Fig. 5. Aminocyclopropane-1-carboxylic acid oxidase (ACO) activity in pawpaw fruit tissue on a fresh weight basis after harvest in 1999 and 2001. Means are from six fruit in 1999 and four fruit in 2001 on each sampling day. Vertical bars on symbols represent \pm SE of the mean. The larger separate vertical bars are Fisher's least significant difference (LSD) at $P=0.05$.

\section{Conclusion}

Ripening pawpaw fruit displayed increases in ethylene production and respiration rate with maxima at $3 \mathrm{~d}$ after harvest. Increasing ethylene evolution coincided with an increase in respiration and a rapid decline in firmness. As the most precipitous decline in fruit firmness preceded the ethylene climacteric, low ethylene levels may be sufficient to initiate the process. The absolute levels of ethylene production and the relative change from preclimacteric rates at harvest to peak values indicate that, although pawpaw shows climacteric patterns of ethylene and respiratory change after harvest, it may be classified as a low ethylene producer when compared to a range of species (Watkins, 2002). Maximum values of ethylene production coincided with the highest activities of both ACS and ACO enzymes as well as the maximum flesh 
ACC content, The coincident increase in ACC content and decline in MACC content in pawpaw suggest a regulation of ethylene production by malonylation of ACC. Therefore, the climacteric development of ethylene production by pawpaw fruit may be regulated by an increase of ACS and ACO activities as well as a decrease in ACC malonyltransferase activity.

\section{Literature Cited}

Alique, R. and J. Zamorano. 2000. Influence of harvest date within the season and cold storage on cherimoya fruit ripening. J. Agr. Food Chem. 48:4209-4216.

Archbold, D.D., R. Koslanund, and K.W. Pomper. 2003. Ripening and postharvest storage of pawpaw. HortTechnology 13:439-441.

Archbold, D.D. and K.W. Pomper. 2003. Ripening pawpaw fruit exhibit respiratory and ethylene climacterics. Postharvest Biol. Tech. 30:99-103.

Biale, J.B. and D.E. Barcus. 1970. Respiratory patterns in tropical fruits of the Amazon Basin. Trop. Sci. 12:93-104.

Brown, B.I., L.S. Wong, A.P. George, and R.J. Nissen. 1988. Comparative studies on the postharvest physiology of fruit from different species of Annona (custard apple). J. Hort. Sci. 63:521-528.

Bruinsma, J. and R.E. Paull. 1984. Respiration during postharvest development of soursop fruit, Annona muricata L. Plant Physiol. 76:131-138.

Darrow, G.M. 1975. Minor temperate fruits, p. 276-277. In: J. Janick and J.N. Moore (eds.). Advances in fruit breeding. Purdue Univ. Press, West Lafayette, Ind.

Dong, J.G., W.T. Kim, W.K Yip, G.A. Thompson, L. Li, A.B. Bennett, and S.F. Yang. 1992. Cloning of a cDNA encoding 1-aminocyclopropane-1-carboxylate synthase and expression of its mRNA in ripening apple fruit. Planta 185:38-45.

Gray, J., S. Picton, J. Shabbeer, W. Schuch, and D. Grierson. 1992. Molecular biology of fruit ripening and its manipulation with antisense genes. Plant Mol. Biol. 19:69-87.

Hoffman, N.E., Y. Liu, and S.F. Yang. 1983. Changes in 1-(malonylamino)cyclopropane-1-carboxylic acid content in wilted wheat leaves in relation to their ethylene production rates and 1-aminocyclopropane1-carboxylic acid content. Planta 157:518-523.

Kosiyachinda, S. and R.E. Young. 1975. Ethylene production in relation to the initiation of respiratory climacteric in fruits. Plant Cell Physiol. 16:595-602.

Kral, R. 1960. A revision of Asimina and Deeringothamnus (Annonaceae). Brittonia 12:233-278.

Lelievre, J., A. Latche, B. Jones, M. Bouzayen, and J. Pech. 1997. Ethylene and fruit ripening. Physiol. Plant. 101:727-739.

Lizada, M.C.C. and S.F. Yang. 1979. A simple and sensitive assay for 1-aminocyclopropane-1-carboxylic acid. Anal. Biochem. 100:140145.

Martin, M.N. and R.A. Saftner. 1995. Purification and characterization of 1-aminocyclopropane-1-carboxylic acid N-malonyltransferase from tomato fruit. Plant Physiol. 108:1241-1249.

Martin, M.N., J.D. Cohen, and R.A. Saftner. 1995. A new 1-aminocyclo- propane-1-carboxylic acid-conjugating activity in tomato fruit. Plant Physiol. 109:917-926.

Martinez, G., M. Serrano, M.T. Pretel, F. Riquelme, and F. Romojaro. 1993. Ethylene biosynthesis and physico-chemical changes during fruit ripening of cherimoya (Annona cherimola Mill.). J. Hort. Sci. 684:477-483.

McGrath, M.J., and C. Karahadian. 1994a. Evaluation of physical, chemical, and sensory properties of pawpaw fruit (Asimina triloba) as indicators of ripeness. J. Agr. Food Chem. 42:968-974.

McGrath, M.J. and C. Karahadian. 1994b. Evaluation of headspace volatiles and sensory characteristics of ripe pawpaws (Asimina triloba) from selected cultivars. Food Chem. 51:255-262.

McKeon, T.A., N.E. Hoffman, and S.F. Yang. 1982. The effect of plant-hormone pretreatments on ethylene production and synthesis of 1-aminocyclopropane-1-carboxylic acid in water-stressed wheat leaves. Planta 155:437-443.

Merodio, C. and J.L. De la Plaza. 1997. Cherimoya, p. 269-288. In: S. Mitra (ed.). Postharvest physiology and storage of tropical and subtropical fruits. CABI, Wallingford, U.K.

Nakatsuka, A., S. Murachi, H. Okunishi, S. Shiomi, R. Nakano, Y. Kubo, and A. Inaba. 1998. Differential expression and internal feedback regulation of 1-aminocyclopropane-1-carboxylate synthase, 1-aminocyclopropane-1-carboxylate oxidase, and ethylene receptor genes in tomato fruit during development and ripening. Plant Physiol. 118:1295-1305.

Oetiker, J.H. and S.F. Yang. 1995. The role of ethylene in fruit ripening. Acta Hort. 398:167-177.

Paull, R.E. 1982. Postharvest variation in composition of soursop_Annona muricata L.) fruit in relation to respiration and ethylene production. J. Amer. Soc. Hort. Sci. 107:582-585.

Poneleit, L.S. and D.R. Dilley. 1993. Carbon dioxide activation of 1-aminocyclopropane-1-carboxylate (ACC) oxidase in ethylene biosynthesis. Postharvest Biol. Technol. 3:191-199.

Sanchez, J.A., J.P. Zamorano, and R. Alique. 1998. Polygalacturonase, cellulase and invertase activities during cherimoya fruit ripening. J. Hort. Sci. Biotech. 73:87-92.

Shiota, H. 1991. Volatile components of pawpaw fruit (Asimina triloba). J. Agr. Food Chem. 39:1631-1635.

Smith, J.J. and P. John. 1993. Activation of 1-aminocyclopropane-1carboxylate oxidase by bicarbonate/carbon dioxide. Phytochemistry 32:1381-1385.

Tsay, L. and M.C. Wu. 1989. Studies on the postharvest physiology of sugar apple. Acta Hort. 258:287-294.

Watkins, C.B. 2002. Ethylene synthesis, mode of action, consequences and control, p. 180-224. In: M. Knee (ed.). Fruit quality and its biological basis. CRC Press, Boca Raton, Fla.

Wills, R.B.H., A. Poi, and H. Greenfield. 1984. Postharvest changes in fruit composition of Annona atemoya during ripening and effects of storage temperature on ripening. HortScience 19:96-97.

Yang, S.F. and N.E. Hoffman. 1984. Ethylene biosynthesis and its regulation in higher plants. Annu. Rev. Plant Physiol. 35:155-189.

Yip, W. and S.F. Yang. 1993. Ethylene metabolism, p. 431-446. In: P.J. Lea (ed.). Methods in plant biochemistry. vol. 9. Academic, London. 